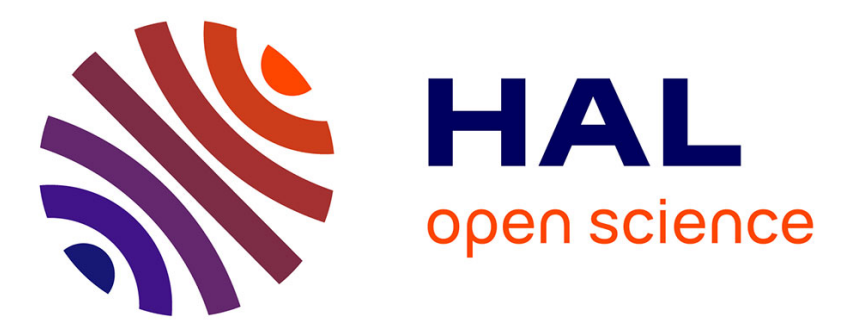

\title{
Is there a structural break in equilibrium velocity in the euro area?
}

Christian Bordes, Laurent Clerc, Vêlayoudom Marimoutou

\section{To cite this version:}

Christian Bordes, Laurent Clerc, Vêlayoudom Marimoutou. Is there a structural break in equilibrium velocity in the euro area?. 2007. hal-00308654

\section{HAL Id: hal-00308654 \\ https://hal.science/hal-00308654}

Submitted on 31 Jul 2008

HAL is a multi-disciplinary open access archive for the deposit and dissemination of scientific research documents, whether they are published or not. The documents may come from teaching and research institutions in France or abroad, or from public or private research centers.
L'archive ouverte pluridisciplinaire HAL, est destinée au dépôt et à la diffusion de documents scientifiques de niveau recherche, publiés ou non, émanant des établissements d'enseignement et de recherche français ou étrangers, des laboratoires publics ou privés. 


\section{NOTES D'ÉTUDES}

\section{ET DE RECHERCHE}

IS THERE A STRUCTURAL BREAK IN EQUILIBRIUM

VELOCITY IN THE EURO AREA?

Christian Bordes, Laurent Clerc and Vêlayoudom Marimoutou

February 2007

NER - E \# 165

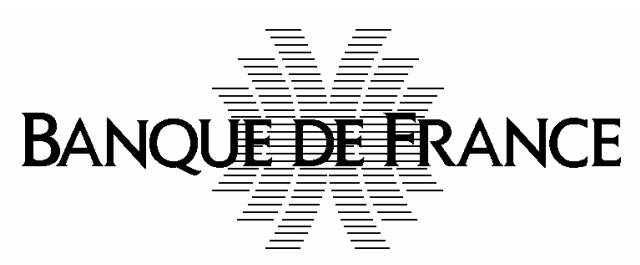




\section{DIRECTION GÉNÉRALE DES ÉTUDES ET DES RELATIONS INTERNATIONALES DIRECTION DE LA RECHERCHE}

\section{IS THERE A STRUCTURAL BREAK IN EQUILIBRIUM}

VELOCITY IN THE EURO AREA?

Christian Bordes, Laurent Clerc and Vêlayoudom Marimoutou

February 2007

NER - E \# 165

Les Notes d'Études et de Recherche reflètent les idées personnelles de leurs auteurs et n'expriment pas nécessairement la position de la Banque de France. Ce document est disponible sur le site internet de la Banque de France «www.banque-france.fr ».

Working Papers reflect the opinions of the authors and do not necessarily express the views of the Banque de France. This document is available on the Banque de France Website "www.banque-france.fr". 


\title{
Is there a structural break in equilibrium velocity in the euro area?
}

\author{
Christian Bordes ${ }^{1, *}$, Laurent Clerc $^{2, \dagger}$ and Vêlayoudom Marimoutou ${ }^{3, \ddagger}$ \\ ${ }^{1}$ Université Paris 1, Centre d'économie de la Sorbonne \\ ${ }^{2}$ Banque de France, Direction de la Recherche \\ ${ }^{3}$ GREQAM, Centre National de la Recherche Scientique (CNRS)
}

16 February $2007^{\S}$

*Tel: +331440782 48; Fax: +331440782 47; E-mail address: christian.bordes@univ-paris1.fr

${ }^{\dagger}$ Tel: +331429238 29; Fax: +331429262 92; E-mail address: laurent.clerc2@banque-france.fr

‡Tel: +331449642 89; Fax: +331449649 21; E-mail address: velayoudom.marimoutou@cnrs-dir.fr

$\S$ The views stated herein are those of the authors and not necessarily those of their respective institutions. We thank Renaud Lacroix and the participants of the Banque de France Reseach seminar for valuable comments. 
Résumé : Nous évaluons dans cet article la stabilité de la vitesse de circulation de M3 dans la zone euro. Pour cela, nous appliquons à cette série une batterie de tests et concluons à la présence de plusieurs ruptures structurelles dont une serait située en 1992-1993 et l'autre en 2000-2001. Ces ruptures affectent tant le niveau que la pente de la vitesse de circulation. Dans un second temps, nous estimons un modèle de vitesse de circulation dans la lignée des travaux d'Orphanides et Porter (2000). Nous trouvons également des signes d'instabilité dans cette relation d'équilibre. Etant donnée l'importance de l'hypothèse de stabilité de la vitesse de circulation, non seulement dans la détermination de la valeur de référence de M3 mais encore dans la stratégie de politique monétaire de la BCE, la présence de ruptures structurelles dans l'évolution de la vitesse de circulation soulève quelques interrogations quant à la pertinence des indicateurs d'excès de liquidité directement dérivés de la valeur de référence et appelle à des ajustements dans la conduite de la politique monétaire unique.

Mots-clefs : Vitesse de circulation de M3 ; Tests de rupture ; BCE.

Codes JEL : E30, E50.

Abstract: We investigate the stability of M3 income velocity in the euro area. We apply a set of breakpoint procedures to examine this issue and conclude that at least one structural change occurred around 2000-2001. We also find evidence of another structural break around 1992-1993. These two breaks seem to affect both the level and the slope of the income velocity of M3. We then estimate a model of equilibrium velocity that factors in the opportunity cost of M3, along the lines suggested by Orphanides and Porter (2000). Here again, we find some evidence of instability in equilibrium velocity. Given the importance of the assumption of stable velocity trends for both the derivation of the reference value and the two-pillar strategy of the Eurosystem, these findings question the relevance of some excess liquidity indicators directly computed from the reference value and may call for some adjustments in the conduct of the ECB's monetary policy.

Keywords: M3 velocity; Breakpoint tests; ECB.

JEL classification: E30, E50. 


\section{Résumé non technique}

Les évolutions récentes de la vitesse de circulation de M3 dans la zone euro nous conduisent à nous interroger sur l'un des fondements du pilier monétaire de la stratégie de politique monétaire de la BCE. En effet, depuis 2001, la croissance de M3 a dépassé de façon systématique sa valeur de référence, i.e. le taux de croissance monétaire compatible avec la stabilité des prix, tandis que, dans le même temps, l'inflation dans la zone euro s'établissait à un niveau proche de $2 \%$ en moyenne. Ces évolutions paradoxales soulèvent la question de la stabilité de la vitesse de circulation de M3 dans la zone euro.

Nous analysons cette question en considérant, dans un premier temps, les propriétés statistiques de la vitesse de circulation de M3 et de M3 corrigé des mouvements de portefeuille. Nous concluons que ces deux variables ne sont pas stationnaires autour d'une tendance déterministe, autrement dit que les chocs affectant la vitesse de circulation de la monnaie dans la zone euro sont de nature permanente plutôt que transitoire. Ensuite, nous appliquons à ces séries une batterie de tests de racine unité robustes à la présence d'une rupture de tendance ainsi que la procédure développée récemment par Bai et Perron (2003). Nous concluons à la présence de plusieurs ruptures structurelles dont une serait située en 1992-1993 et l'autre en 2000-2001. Ces ruptures affectent tant le niveau que la pente de la vitesse de circulation.

Dans un second temps, nous estimons un modèle de vitesse de circulation tenant compte du coût d'opportunité de M3, dans la lignée des travaux d'Orphanides et Porter (2000), et y appliquons à nouveau la procédure de Bai et Perron. Nous trouvons également des signes d'instabilité dans cette relation d'équilibre. Cette approche est complétée par des tests de coïntégration dont il ressort qu'il est difficile de conclure à l'existence d'une relation de long-terme entre la vitesse de circulation de M3 et son coût d'opportunité, sauf dans le cas où les deux ruptures structurelles précédemment mises en évidence sont prises en compte.

Au total, ces résultats tendent à montrer que la vitesse de circulation de la monnaie a connu plusieurs changements structurels importants au cours des trois dernières décennies dans la zone 
euro. Par conséquent, l'existence d'une relation forte, stable et prévisible entre la monnaie et le niveau des prix n'y semble pas garantie.

Les ruptures sont constatées à des périodes durant lesquelles on peut effectivement s'attendre à des chocs sur la vitesse de circulation de la monnaie : la déréglementation financière et la fin de l'encadrement du crédit en Europe continentale dans le milieu des années 1980, les crises du mécanisme de change européen au début des années 1990 et passage à l'euro à l'orée du 21ème siècle.

S'agissant des implications de politique monétaire, nous considérons tout d'abord que ces changements structurels doivent être pris en compte dans la détermination de la valeur de référence.

Deuxièmement, nos résultats nous conduisent à nous interroger sur la pertinence des indicateurs d'excès de liquidité calculés à partir de la valeur de référence actuelle.

Enfin, nos analyses, bien que très préliminaires à ce stade, tendent à monter une relative instabilité de la sensibilité de la vitesse de circulation au coût d'opportunité de M3, avec un possible accroissement de cette dernière depuis le début des années 2000. Cela risque de compliquer la tâche du Conseil des gouverneurs de la BCE dans la mesure où ce dernier doit alors prendre en compte l'impact de sa décision de politique monétaire sur l'évolution de la vitesse de circulation de M3 à court-terme. 


\section{Non technical summary}

Recent developments in M3 velocity in the euro area have raised serious questions about the reliability of M3 growth as a pillar of the ECB's monetary policy strategy. In effect, since 2001, M3 growth has systematically exceeded its reference value, i.e. the level at which monetary developments are considered as compatible with price stability, while HICP inflation has been around $2 \%$ on average. This apparent paradox leads us to investigate the stability of M3 income velocity in the euro area.

We start our analysis by examining the statistical properties of the log-velocity of both M3 and M3 corrected for the estimated impact of portfolio shifts and find that these variables are not trend stationary, i.e. that shocks to velocity tend to be permanent rather than temporary. Then, we apply a set of unit root tests, robust to the presence of a structural break, as well as the breakpoint procedures developed recently by Bai and Perron (2003) to examine this issue. We conclude that at least two structural changes occurred around 2000-2001 and 1992-1993. These two breaks seem to affect both the level and the slope of the income velocity of M3.

We then estimate a model of equilibrium velocity that factors in the opportunity cost of M3, along the lines suggested by Orphanides and Porter (2000) and apply to it the Bai-Perron procedures. Here again, we find some evidence of instability in equilibrium velocity. This approach is completed by cointegration analyses which, in the end, provide no sufficient evidence to conclude to the existence of a long-term relationship between log-velocity and the opportunity cost of M3, but in the case we account for the two structural breaks evidenced before.

All in all, these results tend to show that fundamental changes in M3 velocity trends relative to historical patterns have occurred in the past. Therefore, the existence of a strong, stable and predictable relation between money and prices in the euro area cannot be taken for granted.

The breaks occur around events that one might expect would affect velocity: the deregulation of financial and money markets and the dismantling of credit rationing in several continental European countries in the mid-1980s, the ERM crises in 1992 and 1993 and finally the inception 
of the euro area at the beginning of the 21st century.

Regarding the monetary policy implications, we first argue that these permanent velocity shifts should be made explicit in the derivation of the reference value.

Second, our results cast some doubts on the various measures of excess liquidity computed as the gaps between M3 developments and its actual reference value in nominal or real terms.

Finally, our analysis, only tentative at this stage, tends to show that the sensitivity of the logvelocity to the opportunity cost of M3 could have increased over the recent period, once structural shifts are factored in. This could further complicate the task of the Eurosystem since the ECB's Governing council may need to take into account the impact of monetary policy decisions on short-term developments in M3 velocity. 


\section{Introduction}

Recent developments in $\mathrm{M}^{1}{ }^{1}$ velocity in Euroland have raised serious questions about the reliability of M3 growth as a pillar of the ECB's monetary policy strategy. In effect, this pillar is grounded on the existence of a stable, or at least a predictable, long-term relationship between money and the price level.

However, since 2001, M3 growth has systematically exceeded its reference value, i.e. the level at which monetary developments are considered as compatible with price stability. Meanwhile, HICP inflation has been around $2 \%$ on average, i.e. broadly in line with the Eurosystem's definition of price stability, despites major adverse supply shocks. This may suggest a weakening of the historical link between money and prices in the euro area and would imply a decline in the predictive or the information content of M3 for future price developments.

In order to investigate this issue, we focus on M3 income velocity trends and apply several breakpoint procedures, in particular the newly procedure developed by Bai-Perron (2003) which allow us to jointly test the existence of multiple structural changes. Then, in addition to the usual trend component, we factor in the opportunity cost of holding money along the lines suggested by Orphanides and Porter (2000).

Based on quarterly data from 1980Q1 to 2006Q2, we analyse velocity developments and find some evidence of at least one structural break in trend velocity around 2000-2001. Another structural break is also detected by the procedures around 1992-1993, suggesting that money demand functions display some signs of instability in the euro area. Since 2000-2001, the income velocity of M3 has declined at a stable rate, close to $3.5 \%$.

These results tend to show that fundamental changes in M3 velocity trends relative to historical patterns have occurred and we argue that this should be made explicit in the derivation of the reference value. Moreover, these results cast some doubts on the various measures of excess liquidity computed as the gaps between M3 developments and its actual reference value in nominal or real

\footnotetext{
${ }^{1}$ For the definition of M3, please refer to http://www.ecb.int/stats/money/aggregates/aggr/html/hist.en.html\#skipnavigation
} 
terms.

Section 2 of the paper briefly reviews the framework of the Eurosystem's monetary policy strategy. Section 3 presents the main results of the tests for structural breaks in an univariate framework while section 4 considers a bivariate framework that account for the opportunity costs of holding money. Section 5 draws monetary policy implications and section 6 concludes.

\section{M3 velocity, the reference value and the monetary pillar in Euroland}

On 13 October 1998, the Governing Council of the ECB announced the Eurosystem stabilityoriented monetary policy strategy based on three key elements: a) a quantitative definition of price stability; b) a prominent role for money ("the first pillar of the monetary policy strategy"); c) a broadly based assessment of the outlook for future price developments ("the second pillar of the monetary policy strategy").

The prominent role for money was signalled by the announcement of a reference value for the growth of a broad monetary aggregate (M3). It was made immediately explicit that any deviation of M3 growth would not trigger a mechanistic monetary policy reaction as the relationship between money, prices and activity -summarised as the "income velocity of circulation" of money- may be more complex and less stable in the short run. It was also mentioned that "an important challenge for the monetary analysis undertaken by the ECB is to distinguish temporary changes in velocity from permanent changes so that the information in monetary developments can be interpreted appropriately" (ECB, 2001, p. 47-48).

This strategy was reviewed and clarified in May 2003, when the Governing Council emphasised that the "monetary analysis" (the former "first pillar") will serve as a mean of cross-checking, from a long-term perspective, the indications stemming from the "economic analysis" (the former "second pillar"). Though this decision was interpreted by observers as a downgrading of the role of money in the Eurosystem's monetary policy strategy, money has nevertheless played a significant 
role in the monetary policy decisions of the ECB since December 2005.

Monetary developments in the euro area are assessed with respect to the reference value for the growth of M3, which has been maintained at the rate of $4.5 \%$ since December 1998. The reference value is derived in a manner that is consistent with the Governing Council's definition of price stability (a year-on-year increase in the euro area HICP of below, but close to, $2 \%$ ), a trend in real GDP growth lying in the range of $2 \%$ to $2.5 \%$ and finally an income velocity of M3 declining at a steady rate of between $0.5 \%$ to $1 \%$ per year.

The Eurosystem's monetary policy strategy ${ }^{2}$ relies on two crucial properties assigned to monetary aggregates: 1- Indicator property, i.e. monetary aggregates, in particular M3, should contain helpful information on future price developments; 2- Stability, i.e. M3 should exhibit a stable and predictable relationship with the price level. This stability is generally assessed in the context of money demand frameworks, which relate money to its long-run determinants such as real income, interest rates and the price level. Figure 1 shows the relation between money, prices and activity, as summarised by the income velocity of M3, over the whole sample period.

\footnotetext{
${ }^{2}$ Bordes and Clerc (2007) provide a detailed evaluation of the ECB's monetary policy strategy.
} 


\section{Figure 1}

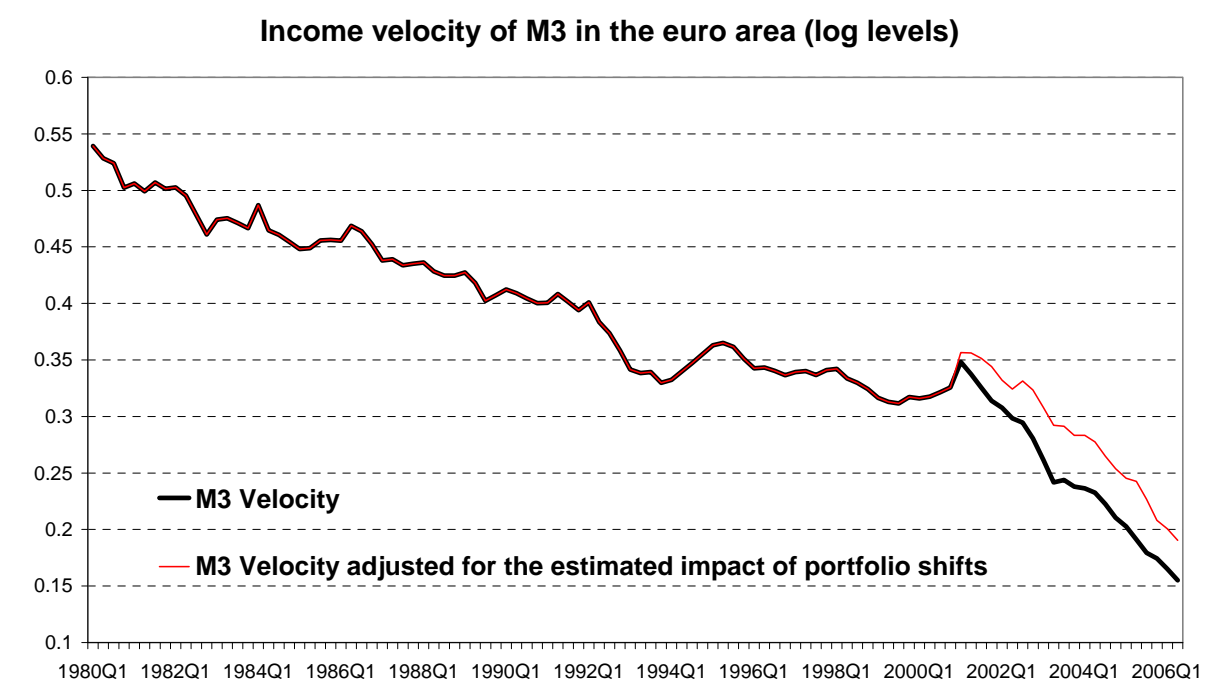

Source: ECB - For the computation of M3 adjusted for the estimated impact of portfolio shifts, refer to Fischer et al. (2006).

Figure 1 points to increasing signs of instability in this long-term relationship since mid-2001, as featured by an apparent break in M3 trend income velocity. So far, the ECB has interpreted these developments as signs of short-term instability, but only of a temporary nature, and considers that the long-run equilibrium for money demand has not changed significantly. The strong demand for M3 seems to be linked to a heightened preference for liquidity induced by a prolonged period of asset price volatility and of historically low interest rates. It is considered that financial, global and economic uncertainties have led to huge portfolio shifts from the less liquid or riskier assets to the instruments included in M3. Indeed, M3 velocity adjusted from the estimated impact of portfolio shifts does not seem to deviate dramatically from its historical patterns up to $2004 .^{3}$

While there are strong arguments for expecting that the short-term instability in M3 velocity will be of a temporary nature only, the fact that this situation has not reversed since 2001 despite considerable changes in the economic environment may also suggest that the apparent break is

\footnotetext{
${ }^{3}$ Buiter et al. (2006) analyse the construction of the portfolio shift-corrected series as an attempt to recover in real time the low frequency component of headline M3 that is correlated with inflation.
} 
more of a structural nature. Indeed, statistical evidence suggests that the unwinding of previous portfolio shifts is almost completed now. In addition, the recovery in economic activity has not led so far to a reduction in the decline of M3 income velocity, whatever the measure considered. Rather, the income velocity of M3 has been declining steadily, at a rate close to $3.5 \%$ per annum, since 2001.

Such developments raise several issues for the Eurosystem's monetary policy strategy as the two properties considered as relevant for the purpose of giving money a prominent role may be challenged:

- Indicator properties: many indicators of monetary imbalances are directly derived from the reference value. This is the case for instance of the nominal and the real money gaps. These indicators should contain relevant information on future price developments and risks to price stability over the medium to the long-run (Gerlach and Svensson, 2003). Instability in equilibrium veloc-

ity should therefore affect their measurement and hence their information content and forecasting abilities;

- Stability: the presence of shifts in equilibrium velocity implies that the relationship between money and the price level is not stable and therefore not easily predictable. In such a case, it is more difficult for the monetary policy maker to exploit this relationship to attain its main policy goal.

\section{Testing for structural changes in the equilibrium velocity of M3 - Univariate analysis}

The derivation of the reference value for M3 is based on the "quantity equation", i.e. the relationship between monetary growth, inflation, real GDP growth and change in velocity. Various approaches were employed to derive the assumption for velocity of circulation ranging from simple time trends to more sophisticated measures derived from money demand models (e.g. for example Masuch et al., 2003).

Based on ECB quarterly data from 1980Q1 to 2006Q2, a simple linear trend model yields the 
following results:

$$
\begin{gathered}
\log V_{t}=\underset{(0.004)}{0.521}-\underset{(7.1 E-05)}{0.0028} t+\varepsilon_{t} \\
\text { note: (standard deviation). }
\end{gathered}
$$

Once annualised, the trend coefficient suggests a decline close to $-1.1 \%$ per year, i.e. a little more pronounced to that underlying the derivation of the reference value. In particular, monetary developments in the euro area since 2001, in a context of subdued economic activity, seem to have accelerated the trend decline of M3 income velocity over the most recent period. Both the constant and the trend coefficient are significant at the $1 \%$ level. However, further econometric analysis raises some cause for concerns.

First, the appropriate method to estimate the univariate trend depends on the time series properties of velocity. The approach based on equation (1) relies explicitly on the assumption that log-velocity is trend stationary. This can be assessed easily by running standard unit root and stationarity tests. Table 1 presents some results for the log-velocity of both M3 and M3 adjusted for the estimated impact of portfolio shifts.

Table 1. Unit root tests of log velocity

\begin{tabular}{ccc}
\hline \hline Variables & ADF & KPSS \\
\hline \hline log-velocity of M3: $v$ & -1.10 & $0.32^{* *}$ \\
$\Delta v$ & $-8.61^{* *}$ & 0.22 \\
log-velocity of M3 adjusted: $v^{a d j}$ & -1.76 & $0.26^{* *}$ \\
$\Delta v^{a d j}$ & $-8.55^{* *}$ & 0.15 \\
\hline \hline
\end{tabular}

ADF: Augmented Dickey-Fuller t-test for unit root against trend-stationary alternative (1 lag based on AIC) or level-stationarity in the case of differiented variable; KPSS: Kiwatosky, Phillips, Schmidt and Shin test for trendstationarity against unit-root alternative; $* *$ (resp. $\left.{ }^{*}\right)$ indicates failure to reject the null hypothesis at the $1 \%$ (resp. $5 \%$ ) significance level.

At a first sight, standard unit root and stationarity tests reject the assumption that M3 income velocity is trend stationary. They also suggest that the linear trend model fares poorly compared to a non stationary alternative. This implies that velocity deviations from trend are highly persistent 
and may suggest that shocks to velocity are permanent rather than temporary. However, such a result may reflect the impact of portfolio shifts on M3 dynamics.

But the same tests also reject the assumption that M3 adjusted for the impact of estimated portfolio shifts is trend stationary.

Another possibility is that the trend is misspecified, in particular if there is a shift in the data generating process or a structural break in the trend component. Such a shift should be taken into account since the ADF test may be distorted if the shift is ignored. We then consider a model of the form:

$$
\log V_{t}=\mu_{0}+\mu_{1} t+f_{t}(\theta)^{\prime} \gamma+x_{t}
$$

where $\theta$ and $\gamma$ are unknown parameters, the errors $\mathrm{x}_{t}$ are generated by an $\mathrm{AR}(\mathrm{p})$ process with possible unit root and $\mathrm{f}_{t}(\theta)^{\prime} \gamma$ is a shift function. Lanne, Lütkepol and Saikkonen (2002) propose unit root tests for the model (2) which are based on estimating the deterministic trend first by a GLS procedure under the unit root null hypothesis and subtracting it from the original series. Then an ADF type test is performed on the adjusted series which also includes terms to correct for the estimation errors in the parameters of the deterministic part.

We assume that the break date is unknown and, as recommended by Lanne et al. (2002), we pick the break date which minimises the GLS objective function used to estimate the parameters of the deterministic part. In what follows, we consider a simple dummy shift function of the form:

$$
f_{t}=d_{1 t}=\begin{aligned}
& 0, t<T_{B} \\
& 1, t \succeq T_{B}
\end{aligned}
$$

More complex forms, based on the exponential distribution function or on a rational function in the lag operator applied to the shift dummy $d_{1 t}$ were also considered without any material differences as regards the main results presented in Table 2 below. 
Table 2. Unit root with one structural break

\begin{tabular}{ccc}
\hline \hline Variables & Test statistic & Suggested break date \\
\hline \hline $\log$ velocity of M3: $v$ & -1.46 & $2001 \mathrm{Q} 1$ \\
$\log$ velocity of M3 adjusted: $v^{a d j}$ & -1.50 & $2001 \mathrm{Q} 1$ \\
\hline \hline
\end{tabular}

Critical values (Lanne et al., 2002).

The procedure detects a breakpoint in the first quarter of 2001 for the log velocity of M3. Interestingly, the same date break is evidenced for the log of the income velocity of M3 adjusted for the estimated impact of portfolio shifts, suggesting that this correction might not be sufficient to consider that the actual deviation of log velocity to its historical patterns is only transitory and due to a one-off but long-lasting factor. Indeed, the tests do not reject the presence of a unit root and leave open the possibility of multiple breaks.

One way to further investigate this issue is to test whether the parameters estimated in relation (1) are stable. Model stability is of particular relevance as monetary policy has to act in a forwardlooking manner in order to maintain price stability. It is also a prerequisite for the definition of the reference value. Hereafter, we implement the tests for parameter instability in linear models developped by Hansen (1992). ${ }^{4}$ Table 3 presents the main results for M3 velocity.

Table 3. L-Stability tests : Log-velocity equation

\begin{tabular}{cccccc}
\hline \hline Sample period & Trend & Constant & Variance & $\mathrm{R}^{2}$ & Joint LC \\
\hline \hline 1980Q1-2006Q6 & $\mathbf{- 0 . 0 0 2 8}$ & $\mathbf{0 . 5 2 4}$ & $\mathbf{0 . 0 0 0 5}$ & $\mathbf{0 . 9 4}$ & $\mathbf{4 . 3}^{* *}$ \\
& $(8.9 \mathrm{E}-05)$ & $(0.003)$ & $(8.7 \mathrm{E}-05)$ & & \\
Individual LC & $0.67^{*}$ & $0.61^{*}$ & $2.94^{*}$ & & \\
1980Q1-2000Q4 & $\mathbf{- 0 . 0 0 2 5}$ & $\mathbf{0 . 5 1 4}$ & $\mathbf{0 . 0 0 0 2}$ & $\mathbf{0 . 9 5}$ & $\mathbf{2 . 0}^{* *}$ \\
& $(6.9 \mathrm{E}-05)$ & $(0.028)$ & $(4.8 \mathrm{E}-05)$ & & \\
Individual LC & $0.72^{*}$ & $0.54^{*}$ & 0.44 & & \\
2001Q1-2006Q2 & $\mathbf{- 0 . 0 0 8 9}$ & $\mathbf{1 . 0 9}$ & $\mathbf{0 . 0 0 0 0 3}$ & $\mathbf{0 . 9 8}$ & $\mathbf{1 . 0}$ \\
& $(0.0001)$ & $(0.012)$ & $(1.7 \mathrm{E}-05)$ & & \\
Individual LC & 0.17 & 0.17 & 0.19 & & \\
\hline \hline
\end{tabular}

*(**): Rejects stability at the asymptotic $5 \%$ level (1\% level).

L-stability tests calculated on the full sample conclude that neither the trend, the constant nor the variance are stable. Indeed, point estimates indicate substantial shifts over the periods under review: in particular, the trend coefficient moves from $-1.0 \%$ per annuum in the first subsample

\footnotetext{
${ }^{4}$ The test is approximately the Lagrange multiplier test of the null of constant parameters against the alternative that parameters follow a martingale.
} 
to $-3.5 \%$ per annuum in the most recent period. The constant term also changes dramatically, reflecting a substantial level shift in velocity. Interestingly, L-statistics fail to reject the null that the time trend, the constant and the variance are constant since 2001Q1, while this is not the case for the previous period.

Most of our results point out the possibility of multiple structural changes. Recently, this issue has been addressed by Bai and Perron $(1998,2003)$ who provide a comprehensive treatment of various issues in the context of multiple structural change models. In particular, Bai and Perron $(1998,2003)$ developed two procedures to test the hypotheses of $m+1$ breaks given $m$ breaks: $1^{\circ}$ a purely sequential procedure that bases each null hypothesis on the previous significant break date generated and therefore gives breakpoint dates that are not necessarily a global minimiser of the sum of squared residuals ; $2^{\circ}$ a procedure - referred to by Carlson, Craig and Schwartz (2000), who apply it to examine the stability of US M2 velocity relation during the period 1964Q1-1998Q4, as the sequential test under the global null - based on $m$ break dates that are global minimisers of the sum of squared residuals. Bai and Perron recommend giving most weight to the second procedure.

Therefore, we apply this second procedure to the case of the linear trend presented in equation (1). We consider the following multiple linear regression with $m$ breaks:

$$
\log V_{t}=x_{t}^{\prime} \beta+z_{t}^{\prime} \delta_{j}+u_{t}
$$

$\mathrm{t}=\mathrm{T}_{j-1}+1, \ldots, T_{j}$ for $\mathrm{j}=1, \ldots, \mathrm{m}+1$. Both $\mathrm{x}_{t}(\mathrm{p} \times 1)$ and $\mathrm{z}_{t}(\mathrm{q} \times 1)$ are vectors of covariates and $\beta$ and $\delta_{j}(j=1, \ldots, m+1)$ are the corresponding vectors of coefficients; $\mathrm{u}_{t}$ is the disturbance at time t. The indices $\left(\mathrm{T}_{1}, \ldots, \mathrm{T}_{m}\right)$ or the break points are treated as unknown. This is a partial structural change model since the parameter vector $\beta$ is not subject to shifts and is estimated using the full sample. The pure structural change model is obtained for $\mathrm{p}=0$ since all the model's coefficients then are subject to change. In what follows, we consider different versions of (4) in which the constant only varies, the trend only varies and finally both the constant and the trend vary (pure structural change model). 
To ensure consistency, limit distribution of the break dates and convergence, some conditions need to be imposed on the regressors. In particular, the procedure by Bai and Perron forbids trending regressors unless they are of the form $\mathrm{t} / \mathrm{T}$ for $\mathrm{t}=1, \ldots, \mathrm{T}$ where $\mathrm{T}$ represents the number of observations, whis is done hereafter. Model (4) is estimated by the ordinary least squares method. We consider two information criteria: the Bayesian information criterion (BIC) and its modified version proposed by Liu et al. (1997) (LWZ). Table 4 displays the main results.

Table 4: Bai-Perron Results for M3 Velocity Models (1980Q1-2006Q2)

\begin{tabular}{|c|c|c|c|c|}
\hline & Number of breaks & Suggested breaks ${ }^{1}$ & $\mathrm{SupF}_{T}$ test & "UDmax / WDmax tests \\
\hline \multirow{3}{*}{$\begin{array}{c}\text { Constant } \\
\text { only }\end{array}$} & BIC: 3 & 1987Q1 & $\operatorname{SupF}_{T}(1)=62.6^{* *}$ & UDmax $=62.6^{* *}$ \\
\hline & LWZ: 1 & 1993Q1 & $\operatorname{SupF}_{T}(2)=27.2^{* *}$ & $\mathrm{WDmax}=62.6^{* *}$ \\
\hline & & 2000Q3 & $\operatorname{SupF}_{T}(3)=36.1^{* *}$ & \\
\hline \multirow{3}{*}{$\begin{array}{l}\text { Trend } \\
\text { only }\end{array}$} & BIC: 2 & 1987Q2 & $\operatorname{SupF}_{T}(1)=0.07$ & $\mathrm{UDmax}=131.2^{* *}$ \\
\hline & LWZ: 2 & 1993Q1 & $\operatorname{SupF}_{T}(2)=46.2^{* *}$ & $\mathrm{WDmax}=212.3^{* *}$ \\
\hline & & 1999Q2 & $\operatorname{SupF}_{T}(3)=131.2^{* *}$ & \\
\hline \multirow{3}{*}{$\begin{array}{l}\text { Constant } \\
\text { and } \\
\text { trend }\end{array}$} & BIC: 3 & 1987Q2 & $\mathrm{SupF}_{T}(1)=0.01$ & $\mathrm{UDmax}=1407816^{* *}$ \\
\hline & LWZ: 1 & 1993Q1 & $\operatorname{SupF}_{T}(2)=1264904^{* *}$ & $\mathrm{WDmax}=2167997^{* *}$ \\
\hline & & $2000 \mathrm{Q} 4$ & $\operatorname{SupF}_{T}(3)=1407816^{* *}$ & \\
\hline
\end{tabular}

${ }^{1}$ Break dates based on minimised sum of squares. ** (resp. *) indicates significance at the $1 \%$ (resp. $5 \%$ ) significance level.

The procedure detects several breaks in trend velocity, whether we consider a shift in the level only, a shift in the coefficient of the time trend only or a combination of both. Date breaks are broadly similar: the tests suggest significant break dates around 1987, 1993 and the end of year 2000. The information criteria however differ regarding the number of selected breaks. Based on the results of Wang (2006), who suggests the use of information criteria to jointly determine the number and the type of multiple structural breaks in the context of finite sample, we here give more weight to the BIC criterion.

Implementing the same procedures to M3 velocity corrected from the estimated impact of portfolio shifts would yield similar results with suggested break dates in 1986Q3, 1993Q1 and 1999Q4.

The date breaks suggested here are consistent with Gerlach (2004), who evidences a weakening 
of M3 growth's ability to help predict future inflation from pre-1987 to the later period and Faruqee (2005) who also finds significant date breaks around 1987 and between the end-2000 and the end2001.

A question arises as regard the break around 1993, which occurs during the ERM crisis period: a visual inspection of Figure 1 reveals a "V-shape" pattern in velocity, a usual feature characterising financial turmoil or periods associated with strong portfolio shifts. Argument is sometimes made that after this episode velocity went back to its historical patterns, suggesting that a temporary - though long-lasting - break occurred in 1993 and that this situation could be compared to the current one. Indeed, after the 1993's break, trend velocity declined at a very similar pace to what has been observed since the end of 2000 , i.e. close to $-3.5 \%$ per annum. As a consequence, one could not rule out the possibility that the current velocity trend could revert with the unwinding of previous portfolio shifts. However, coefficient estimates provided in Table 5 confirm that a significant trend break occurred in 1993 both in the level and the slope and that, in the subsequent period, trend velocity declined at a slower pace, very close to the top range of [-1\%;-0.5\%] used for the derivation of the reference value in December 1998.

Moreover, it is not so clear, from the coefficients estimates provided in Table 5, that a significant change occurred around 1987. The constant only varies and increases, but the change is not statistically significant.

Table 5: Coefficient estimates

\begin{tabular}{ccc}
\hline \hline Period & Constant & Time trend \\
\hline \hline 1980Q1-1986Q4 & 0.518 & -0.0028 \\
& $(0.004)$ & $(0.0002)$ \\
1987Q1-1992Q4 & 0.522 & -0.0028 \\
& $(0.013)$ & $(0.0003)$ \\
19993Q1-2000Q3 & 0.408 & -0.0011 \\
& $(0.013)$ & $(0.0002)$ \\
2000Q4-2006Q2 & 1.065 & -0.0086 \\
& $(0.029)$ & $(0.0003)$ \\
\hline \hline
\end{tabular}

Overall, it thus seems reasonable to consider that M3 log-velocity has been subject to at least two structural changes, affecting both its level and its slope and that these two breaks occurred 
around 1992-1993 and 2000-2001 (cf. Figure 2). Since then, the trend decline of M3 velocity has increased dramatically, from $-0.5 \%$ per annuum to around $-3.5 \%$ and has remained stable so far.

Figure 2

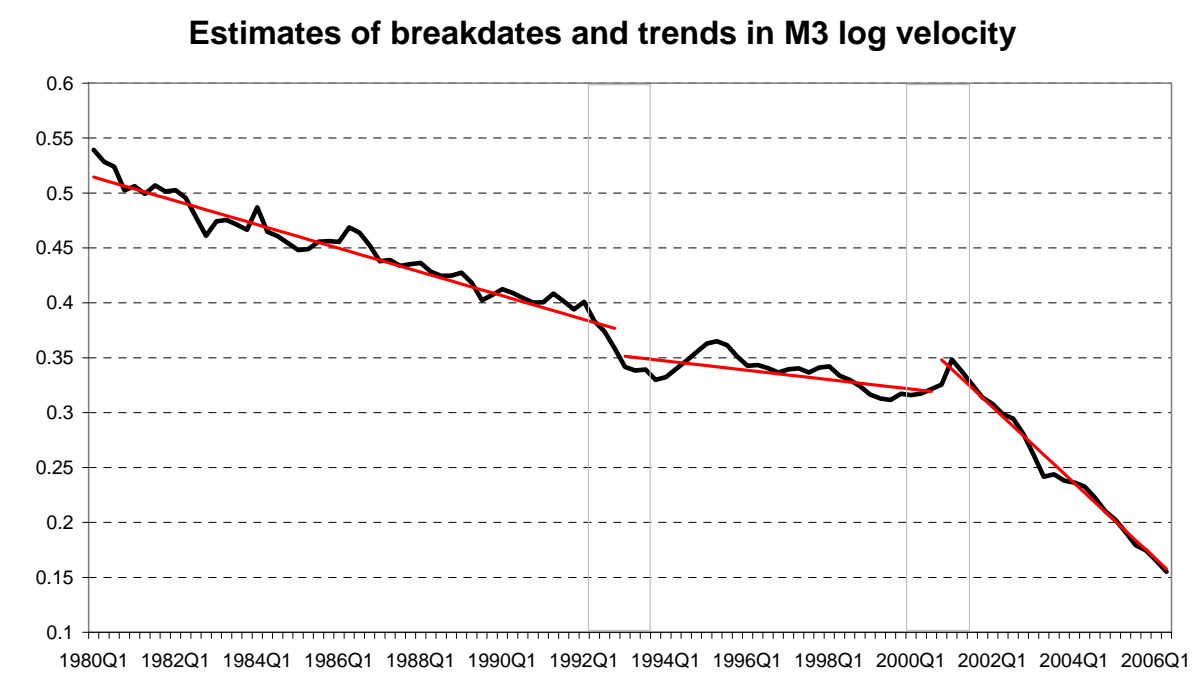

\section{Testing for structural changes in the equilibrium velocity of M3 - bivariate analysis}

Monetary analysis also relies on more complex specifications, in particular money demand frameworks, to assess velocity developments in the euro area. Some of these money demand functions have been challenged over the recent years.

Several studies have shown that the inclusion of stock prices into the equations or the models tend to restore the stability of these money demand functions (see for instance Avouyi-Dovi et al., 2006 or Cartensen, 2004). In such frameworks, stock prices, and more generally asset prices, play a dual role: on the one hand, they act as perfect substitutes of money as suggested by Friedman (1988), on the other they can be considered as proxies for financial market uncertainty, triggering, in the latter case, a precautionary motive for money holding. The above mentioned papers find for instance that a decline in the European stock market would result in a rise in real money holdings and therefore could account for the decline in the euro area velocity of circulation of M3. This story would be consistent with the portfolio shift hypothesis, which occurred in the context of the 
stock market crash at the beginning of 2000 .

However, stock markets have regain momentum since the beginning of 2003 and reached record highs recently without causing the expected upward shift in M3 velocity. Recent developments would on the contrary suggest that the stock market expansion has generated dominant wealth effects that may explain the strong M3 dynamics. Therefore, in the recent period, these refined models have also faced parameter instability as the sign of the stock market price variable may have changed or the error-correction term coefficient may have fallen significantly.

Of course, it may be that the low level of interest rates remains the dominant force driving the strength of the rate of monetary expansion. Indeed, Figure 3 illustrates that M3 velocity and the opportunity cost of M3, computed as the difference between the short-term nominal rate and the average rate paid on M3 balances, exhibit a strong correlation over the past 30 years.

\section{Figure 3}

\section{Velocity and opportunity cost of M3}

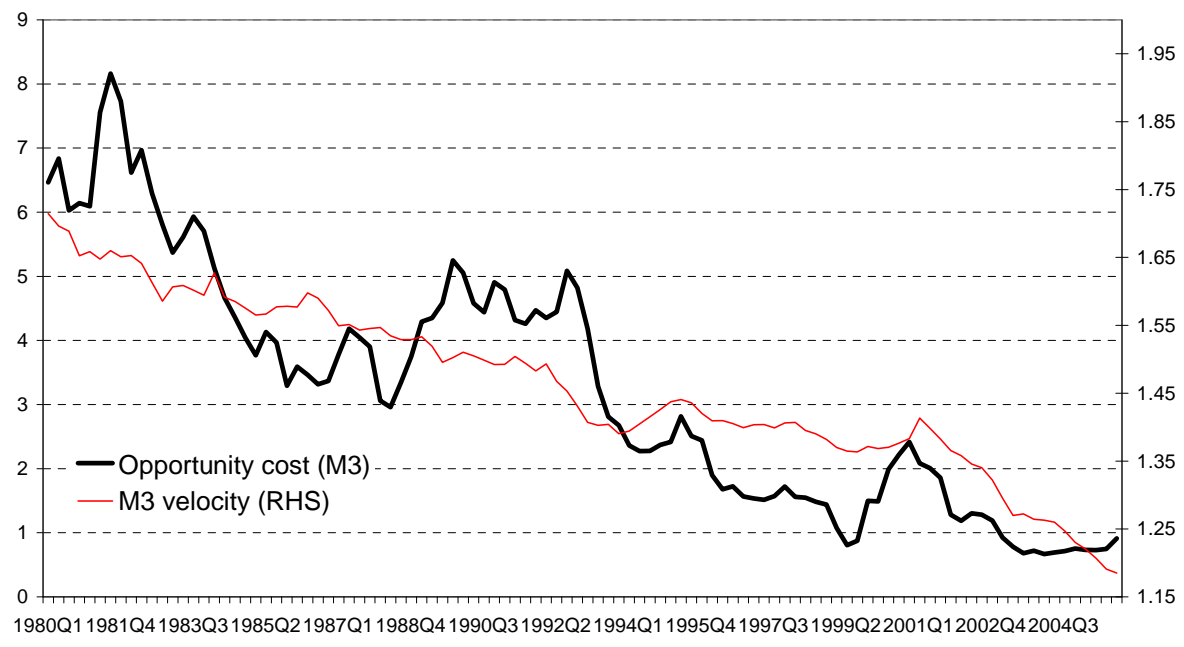

Sources: M3 Velocity, ECB Monthly Bulletin; Opportunity cost of M3, Banque de France.

Indeed, the opportunity cost of money fell dramatically from 2000Q4 to 2003Q3 and remained stable at historically low levels before the ECB started to tighten its monetary policy stance in December 2005.

Would that be sufficient to explain the deviations of M3 velocity from its long-term historical 
patterns? The point here is that interest rates, and the opportunity cost of money, are already imbedded as explanatory variables in standard money demand functions. To conclude that the decline of the opportunity cost of M3 is the main driver of recent monetary developments in the euro area, i.e. of the deviations of M3 or of its velocity from their long-term trends, would then require that either there are strong non-linearities in money demand functions or that the interest rate elasticity of money demand has increased substantially since 2000-2001. In particular, Reynard (2006) argues that very low interest rates can generate nonlinearity due to changes in financial market participation, which would then induce relatively high growth rates in monetary aggregates not followed by high inflation. He considers that part of the recent relatively high growth rates in monetary aggregates are likely to be related to that phenomenon. According to Reynard, those facts act as warning signals when interpreting short-term monetary aggregates growth rate fluctuations. In both cases, this leaves open the possibility of a structural shift in equilibrium velocity in the euro area.

To investigate these issues, we first apply the Bai -Perron procedures to the equilibrium velocity model proposed by Orphanides and Porter (2000). Then, we turn to cointegration rank tests. The aim of this second subsection is not to estimate a money demand function for the euro area, which is far beyond the scope of this paper, but simply to assess the possible existence of structural shifts in a long-term relationship between the velocity and the opportunity cost of M3.

\subsection{Structural change models of equilibrium velocity}

In an influential paper, Orphanides and Porter (2000) propose a general approach to specifying equilibrium velocity. They begin with the simple notion that in the short-run, velocity varies with the opportunity cost of money:

$$
V_{t}=V_{t}^{*}+\alpha_{1} \widetilde{O C_{t}}+\varepsilon_{t}
$$

where $\widetilde{O C}$ denotes the deviations of the opportunity cost of money OC - measured here as the simple difference between the 3-month Treasury bill rate and the share-weighted rate paid on M3 
components - from its long term norm, $\mathrm{V}^{*}$, an estimate of equilibrium velocity; $\alpha_{1}$ is the elasticity of velocity with respect to the opportunity cost, and $\varepsilon$ is a stationary mean zero error term.

Orphanides and Porter allow for the possibility of a trend in $\mathrm{V}^{*}$ that aims at capturing the changes in payment and financial technology. Indeed, Orphanides and Porter are confronted with an upward shift in M2 velocity, possibly stemming from the impact of financial innovations on money demand.

The specification they finally test is therefore:

$$
V_{t}=\alpha_{0}+\alpha_{1} \widetilde{O C_{t}}+\alpha_{2} \text { Time }+\varepsilon_{t}
$$

where $\mathrm{V}_{t}{ }^{*}=\alpha_{0}+\alpha_{2}$ Time and Time is a simple time trend.

We posit the same specification for M3 velocity in the euro area with two important caveats: first, M3 velocity displays a downward trend, not really consistent with the postulated impact of financial innovations on money demand. In the euro area's case, this would rather reflect the positive impact of changes in financial wealth on money demand as some assets included in M3 are interest-bearing and can be used as saving instruments. Second, given the statistical properties of OC in the euro area (see appendix), $\widetilde{O C}$ is computed as the deviations of OC from a stochastic trend estimated by a Hodrick-Prescott filter. ${ }^{5}$

This simple relation does not incorporate explanatory variables to control for the effects of permanent shocks on money that are difficult to model. The Bai and Perron (2003) test allow us to examine whether the omission of such relevant factors has implications for the stability of velocity and to investigate breaks in subsets of parameters in the velocity relation.

This test is particularly well suited to identifying and testing for multiple breaks in equation (6) by estimating the following equation:

$$
V_{t}=\alpha_{0}+\alpha_{1} \widetilde{O C_{t}}+\alpha_{2} \text { Time }+\alpha_{3} D(\tau)+\varepsilon_{t}
$$

\footnotetext{
${ }^{5}$ To implement the Bai and Perron procedures, we also checked that $\widetilde{O C}$ is exogenous (see Table $\mathrm{C}$ in the appendix).
} 
where $\mathrm{D}$ is a dummy variable defined parametrically on an unknown quarter, $\tau$, such that it equals 0 before quarter $\tau$ and 1 thereafter. As in the previous section, Time is normalised by the number of observations, $T$.

We test for all potential sets of breaks. Table 6 presents the suggested date breaks and the test statistics.

Table 6: Bai-Perron Results for M3 Equilibrium Velocity Models (1980Q1-2006Q2)

\begin{tabular}{|c|c|c|c|c|}
\hline & Number of breaks & Suggested breaks $^{1}$ & 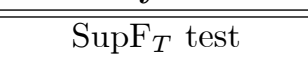 & "UDmax / WDmax tests \\
\hline \multirow{3}{*}{$\begin{array}{c}\text { Constant } \\
\text { only }\end{array}$} & BIC: 2 & 1985Q3 & $\operatorname{SupF}_{T}(1)=0.03$ & UDmax $=8.12^{*}$ \\
\hline & LWZ: 2 & 1994Q3 & $\operatorname{SupF}_{T}(2)=0.17$ & WDmax $=13.6^{*}$ \\
\hline & & 1999Q4 & $\operatorname{SupF}_{T}(3)=8.12^{*}$ & \\
\hline \multirow{3}{*}{$\begin{array}{l}\text { Trend } \\
\text { only }\end{array}$} & BIC: 3 & 1985Q2 & $\operatorname{SupF}_{T}(1)=0.01$ & $\mathrm{UDmax}=44.1^{* *}$ \\
\hline & LWZ: 0 & 1994Q3 & $\operatorname{SupF}_{T}(2)=0.58$ & WDmax $=71.4^{*}$ \\
\hline & & 2001Q1 & $\operatorname{SupF}_{T}(3)=44.1^{* *}$ & \\
\hline $\mathrm{OC}$ & BIC: 1 & 1993Q1 & $\operatorname{SupF}_{T}(1)=0.26$ & UDmax $=0.80$ \\
\hline \multirow{2}{*}{ only } & LWZ: 0 & 1999Q3 & $\operatorname{SupF}_{T}(2)=0.80$ & $\mathrm{WDmax}=1.17$ \\
\hline & & & $\operatorname{SupF}_{T}(3)=0.68$ & \\
\hline \multirow{3}{*}{$\begin{array}{c}\text { Constant } \\
\text { and } \\
\text { Trend }\end{array}$} & BIC: 1 & 1985Q2 & $\operatorname{SupF}_{T}(1)=2.12$ & $\mathrm{UDmax}=114^{* *}$ \\
\hline & LWZ: 0 & 1994Q3 & $\operatorname{SupF}_{T}(2)=3.39$ & $\mathrm{WDmax}=176^{*}$ \\
\hline & & 2001Q1 & $\operatorname{SupF}_{T}(3)=114^{* *}$ & \\
\hline \multirow{3}{*}{$\begin{array}{l}\text { Constant } \\
\text { and } \\
\text { OC }\end{array}$} & BIC: 2 & 1985Q3 & $\operatorname{SupF}_{T}(1)=1.79$ & $\mathrm{UDmax}=9.63$ \\
\hline & LWZ: 2 & 1994Q3 & $\operatorname{SupF}_{T}(2)=9.12^{*}$ & $\mathrm{WDmax}=14.8^{*}$ \\
\hline & & 1999Q4 & $\operatorname{SupF}_{T}(3)=9.63^{* *}$ & \\
\hline \multirow{3}{*}{$\begin{array}{c}\text { Trend } \\
\text { and } \\
\text { OC }\end{array}$} & BIC: 1 & $1985 \mathrm{Q} 2$ & $\mathrm{SupF}_{T}(1)=2.12$ & $\mathrm{UDmax}=114^{* *}$ \\
\hline & LWZ: 0 & 1994Q3 & $\operatorname{SupF}_{T}(2)=3.39$ & $\mathrm{WDmax}=176^{*}$ \\
\hline & & 2001Q1 & $\operatorname{SupF}_{T}(3)=114^{* *}$ & \\
\hline \multirow{3}{*}{$\begin{array}{l}\text { Constant } \\
\text { Trend } \\
\text { and OC }\end{array}$} & BIC: 3 & $1985 \mathrm{Q} 2$ & $\operatorname{SupF}_{T}(1)=31.2^{* *}$ & $\mathrm{UDmax}=6305^{* *}$ \\
\hline & LWZ: 2 & 1992Q2 & $\operatorname{SupF}_{T}(2)=42.3^{* *}$ & WDmax $=9312^{*}$ \\
\hline & & $2000 \mathrm{Q} 4$ & $\operatorname{SupF}_{T}(3)=6305^{* *}$ & \\
\hline
\end{tabular}

${ }^{1}$ Break dates based on minimised sum of squares. ${ }^{* *}\left(\right.$ resp. $\left.{ }^{*}\right)$ indicates significance at the $1 \%$ (resp. $5 \%$ ) significance level.

The inclusion of $\widetilde{O C}$ slightly modifies the results presented in section 2 in that it contributes to "stabilise" the velocity equation: the breaks selected according to both the BIC and the LWZ criteria tend to be slightly less numerous ( 1 or 2 breaks instead of 2 or 3 previously). However, the suggested break dates are still roughly located at the same periods with breaks occurring in the mid-1980s, around 1992-1994 and 1999-2001. As regards the other results, not presented in the table, when the sensitivity of the log velocity of $\mathrm{M} 3$ with respect to $\widetilde{O C}$ is allowed to change, it displays the following pattern: the coefficient is usually not significant at the beginning of the 
sample, i.e. during the first sub-period detected by the procedure, but become so at the end of the sample. It is statistically significant, increases and almost doubles when it is allowed to change with the time trend coefficient between the last two periods. However, when all the coefficients are allowed to vary, the sensitivity of M3 log velocity relative to $\widetilde{O C}$ does not materially change after 2000Q4 and it is barely significant (at the 10\% level). For the other coefficients, the estimates are then very close to those presented in Table 5, suggesting that a simple time-trend specification is sufficient to account for M3 velocity developments.

\subsection{Cointegration rank tests}

Another way to tackle these issues is to consider whether the log-velocity of money and the opportunity cost of M3, OC, are cointegrated. For these two variables, there may be a deterministic linear trend and unit root tests provide evidence for a stochastic trend as well. the analyses carried out so far can not rule out the possibility of multiple shifts. In what follows, we try to account for these shifts by imposing structural break dates in 1992Q2 and 2000Q4 as suggested in Table 6 .

We have performed cointegrating rank tests, with and without the shift dummies. The results are given in Table 7. A linear trend, which is not assumed to be orthogonal to the cointegrating relation is included in all the tests, unless stated otherwise. As in the previous sub-section, it aims at capturing in a very simple manner the net or combined effects of financial innovations, changes in payment technologies and changes in financial wealth. The lag order suggested by the AIC, the Final Prediction error, the HQ and the Schwartz criteria is 2 and therefore used in all the tests. We refer to Johansen, Mosconi and Nielsen (2000) to carry out cointegration analysis in the presence of two structural breaks in the deterministic trend. 
Table 7: Tests for the cointegrating rank of the equilibrium velocity system

\begin{tabular}{cccccc}
\hline \hline \multirow{2}{*}{ Test } & & Null & Test & \multicolumn{2}{c}{ Critical values } \\
Johansen & $\mathrm{C}$ & $\mathrm{r}=0$ & 19.61 & 17.98 & 20.16 \\
& & $\mathrm{r}=1$ & 4.95 & 7.60 & 9.14 \\
Johansen & $\mathrm{DT}$ & $\mathrm{r}=0$ & 16.90 & 23.32 & 25.73 \\
& & $\mathrm{r}=1$ & 2.66 & 10.68 & 12.45 \\
S\&L & $\mathrm{DT}$ & $\mathrm{r}=0$ & 14.01 & 13.88 & 15.76 \\
& & $\mathrm{r}=1$ & 0.99 & 5.47 & 6.79 \\
Johansen & $\mathrm{DT}+$ & $\mathrm{r}=0$ & $52.99^{*}$ & 44.21 & 47.58 \\
et al. & shifts & $\mathrm{r}=1$ & 13.43 & 22.11 & 24.65 \\
\hline \hline
\end{tabular}

Notes: sample period: 1982Q3-2006Q2; Critical values from Johansen 1995 for Johansen test, Lütkepohl \& Saikkonen (2000) for the S\&L test and Johansen, Mosconi and Nielsen (2000) for the Johansen et al. test. C stands for a model that factors in a constant only, DT for a deterministic trend.

It turns out, from Table 7, that none of the tests find cointegration if no structural shift dummies are included whereas there is some evidence for a cointegration relation if two structural breaks are included. On the one hand, no cointegration would mean that the decrease in the opportunity cost of M3 cannot fully account for the acceleration in the decline of log velocity since 2001. On the other hand, cointegration is accepted only when multiple structural shifts are embedded in the relation, pointing to the fact that equilibrium velocity is not stable.

To complement this analysis, we apply the residual-based tests for cointegration in models with regime shifts proposed by Hansen and Gregory (1996) which is robust to the presence of one-time regime shift. Three different models are considered in this approach:

1) a model with a level shift in the cointegration relation shift denoted by $\mathrm{C}$ :

$$
\log V_{t}=\alpha_{0}+\alpha_{1} \varphi_{t \tau}+\alpha_{2} O C_{t}+\varepsilon_{t}
$$

$\mathrm{t}=1, \ldots, \mathrm{n}$, with $\varphi_{t \tau}=0$ if $\mathrm{t} \preccurlyeq[n \tau]$ or $\varphi_{t \tau}=1$ if $\mathrm{t} \succ[n \tau]$ where the unknown parameter $\tau \in(0,1)$ denotes the relative timing of the change point and [ ] denotes integer part. The break date is treated as unknown. The cointegration test is computed for each possible regime shift $\tau \in T$ and the timing of the break is set at the smallest value across all possible break points; 
2) a model of level shift with trend $(\mathrm{C} / \mathrm{T})$ :

$$
\log V_{t}=\alpha_{0}+\alpha_{1} \varphi_{t \tau}+\alpha_{2} O C_{t}+\alpha_{3} \text { Time }+\varepsilon_{t}
$$

3) a model of regime shift $(\mathrm{C} / \mathrm{S})$ :

$$
\log V_{t}=\alpha_{0}+\alpha_{1} \varphi_{t \tau}+\alpha_{2} O C_{t}+\alpha_{3} O C_{t} \varphi_{t \tau}+\varepsilon_{t}
$$

where both the constant and the slope coefficient are allowed to shift. In what follows, we test the null of no cointegration against the alternative of cointegration with either one level-, time- or regime- shift. Table 8 reports the test statistics as well as the estimated breakpoint.

Table 8: testing for regime shifts in equilibrium velocity

\begin{tabular}{cccc}
\hline \hline & & \multicolumn{2}{c}{ Quarterly data: 1980Q1-2006Q2 } \\
\cline { 3 - 4 } & Model & Test & Breakpoint \\
\hline \hline ADF & $\mathrm{C}$ & -2.54 & 2000Q4 \\
& $\mathrm{C} / \mathrm{T}$ & -2.51 & $2000 \mathrm{Q} 3$ \\
& $\mathrm{C} / \mathrm{S}$ & -2.40 & $2001 \mathrm{Q} 1$ \\
\hline Phillips (1987) $\mathrm{Z}_{t}$ & $\mathrm{C}$ & -2.41 & $2001 \mathrm{Q} 1$ \\
& $\mathrm{C} / \mathrm{T}$ & -2.62 & $2001 \mathrm{Q} 1$ \\
& $\mathrm{C} / \mathrm{S}$ & -2.53 & $2001 \mathrm{Q} 1$ \\
\hline Phillips (1987) $\mathrm{Z}_{\alpha}$ & $\mathrm{C}$ & -12.74 & $2001 \mathrm{Q} 1$ \\
& $\mathrm{C} / \mathrm{T}$ & -15.31 & $2001 \mathrm{Q} 1$ \\
& $\mathrm{C} / \mathrm{S}$ & -13.49 & $2001 \mathrm{Q} 1$ \\
\hline \hline
\end{tabular}

All the tests fail to reject the null of no cointegration, even when we allow for one period shift. According to these tests, would there be a break date, it will be located between 2000Q3 and 2001Q1.

Overall, Tables 7 and 8 lead us to the conclusion that there is no sufficient evidence to conclude to the existence of a stable long-run relationship between the log velocity of M3 and its opportunity cost. The only case where the null of no cointegration is rejected occurs when we allow for two structural breaks. 


\section{$5 \quad$ Monetary policy implications}

The prominent role for money in the Eurosystem's monetary policy strategy is supported by the existence of a strong and stable relationship between inflation and money growth over the long-term in the euro area.

However, we provide some evidence that this long-run relationship has broken down and that it has been affected by several velocity shocks, which, according to our findings, are permanent. Therefore, the existence of a strong, stable and predictable relation between money and prices in the euro area cannot be taken for granted.

Our results lead us to conclude that there were at least two structural breaks in the log-velocity of M3: one around 1992-1994 and one around 2000-2001. Some tests also point another break date around 1985-1987. Though it is difficult to fully rationalise these breaks, they occur around events that one might expect would affect velocity: first, the deregulation of financial and money markets and the dismantling of credit rationing in several continental European countries (e.g. France, 1986; Spain 1987; Finland 1986-1987; Ireland 1985; Italy 1987-1988 to name a few), consistent with an upward shift in velocity as evidenced in table 5; second, the ERM crises of 1992 and 1993, as a result of the conjunction of tight monetary policies in the aftermath of the German Reunification, a fixed exchange rate regime (EMS) and economies in recession. This is consistent with a downward shift in velocity as GDP receded and as money demand eventually increased in the wake of financial market uncertainty. Finally, the inception of the euro and lately the cash changeover are good candidate for a third structural change.

As regards the stability issue, log-velocity of M3 cannot be considered as trend stationary. However, despites considerable changes in the economic environment, the velocity of M3 has declined at a remarkably stable pace of around $-3.5 \%$ per year since 2001 . Therefore, one can not conclude that there is no link between money and prices but only that this link has changed other time. These fundamental changes in the behaviour of velocity trends relative to its historical patterns 
should be made explicit in the derivation of the reference value. ${ }^{6}$ The key point here is that the velocity assumption has been fixed in, and has remained unchanged since, December 1998, at a time the Governing Council faced "extreme" uncertainty (Issing, 2006) and was on the eve of the euro. This is of upmost importance for the two-pillar strategy of the ECB. As argued by Beck and Wieland (2006), the Eurosystem's monetary policy strategy can be justified by allowing for imperfect knowlegde regarding unobservable variables. In their set up, Beck and Wieland interpret the idea of "cross-checking", used by the ECB since May 2003, as a situation in which the central bank regularly checks whether a filtered money growth adjusted for both output and velocity trends averages around the inflation objective and eventually adjusts its key interest rates when it obtains successive signals of a sustained deviation of inflation from target. However, this strategy is questioned when unforseen permanent shifts in velocity occur. In that case, the information content of long-run money growth would depend on how quickly the central bank learns the new parameter values.

As regards predictability, these developments raise two issues.

Once the diagnosis of instability in the relation between money and prices has been made, the first issue is how to anticipate the next shift, or even how to identify that a break has occurred in real time so as to eventually adjust the conduct of monetary policy. This is particularly crucial in the context of a forward-looking monetary policy. There might be no other solution than to carry out in-depth monetary analysis in real time as practised currently by the ECB (cf. Fischer et al., 2006 for an illustration).

The second issue relates to the forecasting ability of monetary indicators computed against the background of a reference value that may be not reliable anymore. The essence of our paper is similar to that of Orphanides and Porter (2000) in that it suggests that the recent deterioration of the information content of monetary developments for future price developments, using an incorrect assumption for trend velocity, should be reversed once the apparent shifts in velocity are accounted

\footnotetext{
${ }^{6}$ Instability of velocity may call for more radical solutions. For instance, in mid-1993, the Fed responded to the velocity shift of M2 by formally downgrading this monetary aggregate as an indicator of the state of the economy.
} 
for. Providing econometric evidence on that issue remains to be done and might be a scope for future research.

A direct implication of that is that one should be very cautious in interpreting estimates of excess liquidity directly measured by the deviations of M3 growth from the reference value. These indicators, whether M3 is corrected from the estimated impact of portfolio shifts or not, are continuously growing since 2001. But this may simply reflect the fact that these measures rely on the past velocity trends we find have broken down recently. Once the structural shift is factored in the derivation of the reference value, the so-called "excess liquidity" simply vanishes in the euro area. Figure 4 and 5 present the measures of the nominal and the real gaps, defined as the difference between the actual level of M3 and the level of M3 that would have resulted from constant M3 growth at its reference value, and compare them to what would have resulted if structural shifts were accounted for.

Figure 4

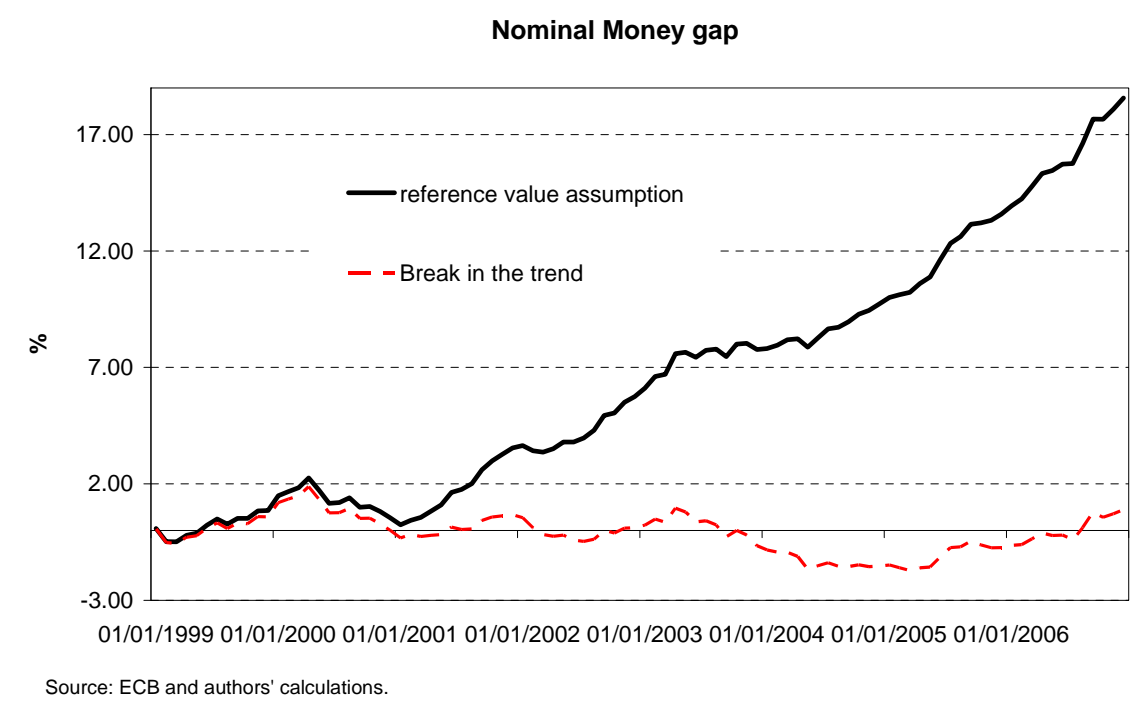




\section{Figure 5}

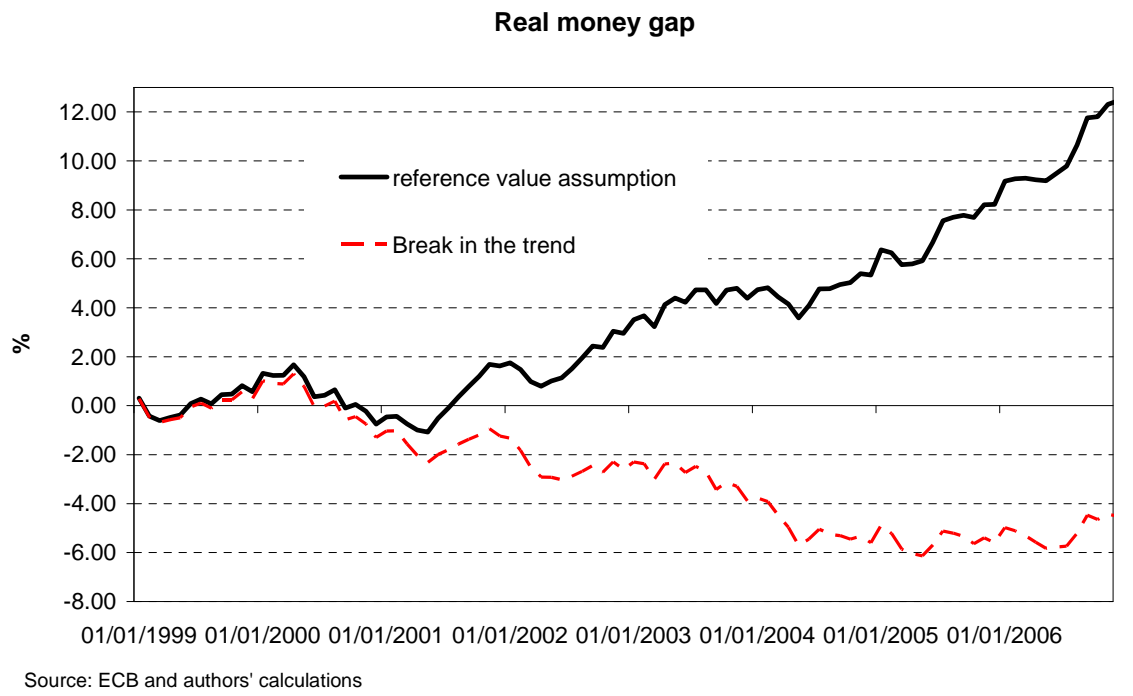

The real gap takes into account the part of the accumulated liquidity that has been absorbed by inflation. It is negative as the nominal gap is close to zero and inflation, since November 1999, has always exceeded $1.5 \%$, the implicit inflation rate used to derive the actual reference value. Based only on these two indicators, it is difficult to argue that there are risks to price stability in the euro area. It should be noted however that we do not question the fact that there is ample liquidity circulating in the euro area, but that we consider that this is better evidenced by a bunch of other indicators, such as historically low nominal and real interest rates, low risk premium, low credit spreads or very accommodative monetary and financial conditions.

Finally, our analysis, only tentative at this stage, tends to show that the sensitivity of logvelocity to the opportunity cost of money could have increased over the recent period. This finding may have important implications for the Eurosystem's monetary policy conduct. In particular, as the own rate of M3 responds sluggishly to changes in short-term interest rates, the opportunity cost of M3 and therefore M3 velocity are now directly impacted by interest rates' decisions. This could seriously complicate the task of the Eurosystem since the ECB's Governing council may need to take into account the impact of monetary policy decisions on short-term developments in M3 velocity. 


\section{Conclusion}

Our results tend to show that fundamental changes in M3 velocity trends relative to historical patterns have occurred over the recent years. We evidence several structural breaks that are located around events one might expect would affect velocity: the deregulation of financial and money markets and the dismantling of credit rationing in several continental European countries in the mid-1980s, the ERM crises in 1992 and 1993 and finally the inception of the euro area at the beginning of the 21st century.

Regarding monetary policy implications, we first argue that these permanent velocity shifts should be made explicit in the derivation of the reference value. Second, our results cast some doubts on the various measures of excess liquidity computed as the gaps between M3 developments and its actual reference value in nominal or real terms.

The negative trend in the income velocity of money is a feature of the euro area. One would rather expect that financial development and financial innovations would result in an upward shift or trend in the velocity of money. The negative time trend in the euro area is consistent with an income velocity of M3 higher than one. As income can be considered as a proxy for financial wealth, one can not rule out that the recent acceleration in the decrease of M3 velocity might reflect the fact that a given change in income corresponds to a greater change in total wealth, featuring an increase in financial wealth over the recent years. Wealth effects can complicate the conduct of monetary policy in two ways, as broad monetary aggregates, such as M3, incorporate monetary instruments that have rate of return which are very close to those of non-monetary financial assets.

First, one can not rule out, at least in the short-run, that monetary tightening can be accompanied by a further decrease in M3 velocity (i.e. an acceleration in M3 growth).

Second, the success of the ECB in achieving and maintaining low inflation in the euro area may also have contributed to blur the distinction between monetary and financial assets as credibility gains may have reduced inflation risk premia. In such a context, the acceleration in the decline of M3 income velocity might be another illustration of the "paradox of credibility". 


\section{References}

1. Avouyi-Dovi, S., Brun, M., Dreyfus, A., Drumetz, F., Oung, V., and Sahuc, J.-G. (2006), "La fonction de demande de monnaie pour la zone euro: un réexamen", Banque de France, Notes d'Etude et de Recherche, NER-E \#42, May.

2. Bai, J. and Perron, P. (1998): "Estimating and Testing Linear Models with Multiple Structural Changes", Econometrica, 66, 47-78.

3. Bai, J. and Perron, P. (2003): "Critical Values for Multiple Structural Change Tests", Econometrics Journal, 6, 72-78.

4. Beck, G. W. and Wieland W. (2006): "Money in Monetary Policy Design: A formal Characterization of ECB-Style Cross-Checking", presented at the EEA 2006 Annual Congress in Vienna, October 4, 2006 version.

5. Bordes, C. and Clerc, L. (2007): "Price stability and the ECB's monetary policy strategy," Journal of Economic Surveys (Forthcoming).

6. Buiter, W., Nielsen, E. F. and Vernazza D. (2006): "The ECB and its Monetary Analysis", European Weekly Analyst, Golman Sachs Economic Research, No 06/29, July 27.

7. Carlson, J. B., Craig, B. and Schwarz, J. C. (2000): "Structural Uncertainty and breakpoint Tests: An Application to Equilibrium Velocity", Journal of Economics and Business, 52, $101-115$.

8. Cartensen, K. (2004), "Stock market downsizing and the stability of EMU money demand", Manuscript, Kiel Institute for World Economics.

9. $\operatorname{ECB}(2001)$, The Monetary Policy of the ECB, European Central Bank.

10. ECB (2004), The Monetary Policy of the ECB, European Central Bank. 
11. Faruqee, H. (2005): "Declining Money Velocity in the Euro Area: Implications for the ECB's Monetary Policy Analysis", IMF Country reports, Euro area policies: selected issues, $\mathrm{n}^{\circ} 05$ $266,32-61$.

12. Fischer, B., Lenza, M., Pill H. and Reichlin, L. (2006): "Money and monetary policy: The ECB experience 1999-2006", contribution to The role of money: money and monetary policy in the twenty-first century, 4th ECB Central Banking Conference, Francfurt, November.

13. Friedman, M. (1988): "Money and the Stock Market", Journal of Political Economy, No 96, $221-245$.

14. Gerlach, S. (2004): "Interest Rate Setting by the ECB: Words and Deeds", CEPR Discussion Paper, No. 4775.

15. Gerlach, S. and Svenson, L. (2003): "Money and inflation in the euro are: A case for monetary indicators?", Journal of Monetary Economics, 50, 1649-1672.

16. Gregory, A. W. and Hansen, B. E. (1996): "Residual-based tests for cointegration in models with regime shifts", Journal of Econometrics, 70, 99-126.

17. Hansen, B. E. (1992): “Testing for Parameter Instability in Linear Models", Journal of Policy Modeling, 14(4), 517-533.

18. Issing, O. (2006): "The ECB's Monetary Policy Strategy: Why did we choose a two Pillar Approach", contribution to The role of money: money and monetary policy in the twenty-first century, 4th ECB Central Banking Conference, Francfurt, 10 November.

19. Johansen, S. (1995): Likelihood-based Inference in Cointegrated Vector Autoregressive Models, Oxford University Press, Oxford.

20. Johansen, S., Mosconi, R. and Nielsen, B. (2000): "Cointegration analysis in the presence of structural breaks in the deterministic trend", Econometrics Journal, 3, 216-249. 
21. Lanne, M., Lütkepol, H. and Saikkonen, P. (2002): "Comparison of unit root tests for time series with a level shift at unknown time", Journal of Time Series Analysis, 23, 667-685.

22. Liu, J., Wu, S., Zidek, J.V. (1997): “On segmented multivariate regression”, Statistica Sinica $7,497-525$.

23. Masuch, K., Nicoletti-Altimari, S., Pill, H. and Rostagno M. (2003): "The role of money in monetary policy making", in Background Studies for the ECB's Evaluation of its Monetary Policy Strategy, Otmar Issing Ed., European Central Bank, November.

24. Orphanides, A. and Porter, R. D. (2000): "P* Revisited: Money-Based Inflation Forecasts with a Changing Equilibrium Velocity", Journal of Economics and Business, 52, 87-100.

25. Perron, P. and Qu, Z. (2004): "Estimating Restricted Structural Change Models", Manuscript Boston University.

26. Phillips, P. C. B. (1987): "Time series regression with a unit root", Econometrica, 55, 277301.

27. Reynard, S. (2006): "Money and the Great Disinflation", Swiss National Bank Working Papers, 2006-7, January.

28. Wang, Z. (2006): "The joint determination of the number and the type of structural changes", Economic Letters, 93, 222-227. 


\section{APPENDIX}

Table A. Unit root tests of the opportunity cost of M3

\begin{tabular}{ccc}
\hline \hline Variables & ADF & KPSS \\
\hline \hline Opportunity cost: OC & -2.97 & $0.15^{*}$ \\
$\Delta O C$ & $-6.43^{* *}$ & 0.06 \\
\hline \hline
\end{tabular}

ADF: Augmented Dickey-Fuller t-test for unit root against trend-stationary alternative (1 lag based on AIC) or level-stationarity in the case of differiented variable; KPSS: Kiwatosky, Phillips, Schmidt and Shin test for trendstationarity against unit-root alternative; ${ }^{* *}\left(\right.$ resp. $\left.{ }^{*}\right)$ indicates failure to reject the null hypothesis at the $1 \%$ (resp. $5 \%)$ significance level.

Table B. Unit root with one structural break

\begin{tabular}{ccc}
\hline \hline Variables & Test statistic & Suggested break date \\
\hline \hline Opportunity cost of $M 3:$ OC & -2.72 & $1999 \mathrm{Q} 4$ \\
\hline \hline
\end{tabular}

Critical values (Lanne et al., 2002).

Table C. Pairwise Granger Causality Test

\begin{tabular}{ccc}
\hline \hline Null Hypothesis & F-Statistic & Probability \\
\hline \hline log V does not Granger Cause $\widetilde{O C}$ & 0.36 & 0.69 \\
$\widetilde{O C}$ does not Granger Cause $\log \mathrm{V}$ & 3.67 & 0.03 \\
\hline \hline
\end{tabular}

Sample 1980Q1-2006Q2 - 2 lags. 


\section{Notes d'Études et de Recherche}

1. C. Huang and H. Pagès, "Optimal Consumption and Portfolio Policies with an Infinite Horizon: Existence and Convergence," May 1990.

2. C. Bordes, «Variabilité de la vitesse et volatilité de la croissance monétaire : le cas français », février 1989.

3. C. Bordes, M. Driscoll and A. Sauviat, "Interpreting the Money-Output Correlation: Money-Real or Real-Real?," May 1989.

4. C. Bordes, D. Goyeau et A. Sauviat, «Taux d'intérêt, marge et rentabilité bancaires : le cas des pays de l'OCDE », mai 1989.

5. B. Bensaid, S. Federbusch et R. Gary-Bobo, «Sur quelques propriétés stratégiques de l'intéressement des salariés dans l'industrie », juin 1989.

6. O. De Bandt, «L'identification des chocs monétaires et financiers en France: une étude empirique », juin 1990.

7. M. Boutillier et $\mathrm{S}$. Dérangère, « Le taux de crédit accordé aux entreprises françaises : coûts opératoires des banques et prime de risque de défaut », juin 1990.

8. M. Boutillier and B. Cabrillac, "Foreign Exchange Markets: Efficiency and Hierarchy," October 1990.

9. O. De Bandt et P. Jacquinot, «Les choix de financement des entreprises en France : une modélisation économétrique », octobre 1990 (English version also available on request).

10. B. Bensaid and R. Gary-Bobo, "On Renegotiation of Profit-Sharing Contracts in Industry," July 1989 (English version of NER n ${ }^{\circ}$ 5).

11. P. G. Garella and Y. Richelle, "Cartel Formation and the Selection of Firms," December 1990.

12. H. Pagès and H. He, "Consumption and Portfolio Decisions with Labor Income and Borrowing Constraints," August 1990.

13. P. Sicsic, « Le franc Poincaré a-t-il été délibérément sous-évalué ?», octobre 1991.

14. B. Bensaid and R. Gary-Bobo, "On the Commitment Value of Contracts under Renegotiation Constraints," January 1990 revised November 1990.

15. B. Bensaid, J.-P. Lesne, H. Pagès and J. Scheinkman, "Derivative Asset Pricing with Transaction Costs," May 1991 revised November 1991.

16. C. Monticelli and M.-O. Strauss-Kahn, "European Integration and the Demand for Broad Money," December 1991.

17. J. Henry and M. Phelipot, "The High and Low-Risk Asset Demand of French Households: A Multivariate Analysis," November 1991 revised June 1992.

18. B. Bensaid and P. Garella, "Financing Takeovers under Asymetric Information," September 1992. 
19. A. de Palma and M. Uctum, "Financial Intermediation under Financial Integration and Deregulation," September 1992.

20. A. de Palma, L. Leruth and P. Régibeau, "Partial Compatibility with Network Externalities and Double Purchase," August 1992.

21. A. Frachot, D. Janci and V. Lacoste, "Factor Analysis of the Term Structure: a Probabilistic Approach," November 1992.

22. P. Sicsic et B. Villeneuve, « L'afflux d'or en France de 1928 à 1934 », janvier 1993.

23. M. Jeanblanc-Picqué and R. Avesani, "Impulse Control Method and Exchange Rate," September 1993.

24. A. Frachot and J.-P. Lesne, "Expectations Hypothesis and Stochastic Volatilities," July 1993 revised September 1993.

25. B. Bensaid and A. de Palma, "Spatial Multiproduct Oligopoly," February 1993 revised October 1994.

26. A. de Palma and R. Gary-Bobo, "Credit Contraction in a Model of the Banking Industry," October 1994.

27. P. Jacquinot et F. Mihoubi, «Dynamique et hétérogénéité de l'emploi en déséquilibre », septembre 1995.

28. G. Salmat, «Le retournement conjoncturel de 1992 et 1993 en France : une modélisation VAR », octobre 1994.

29. J. Henry and J. Weidmann, "Asymmetry in the EMS Revisited: Evidence from the Causality Analysis of Daily Eurorates," February 1994 revised October 1994.

30. O. De Bandt, "Competition Among Financial Intermediaries and the Risk of Contagious Failures,” September 1994 revised January 1995.

31. B. Bensaid et A. de Palma, «Politique monétaire et concurrence bancaire », janvier 1994 révisé en septembre 1995.

32. F. Rosenwald, « Coût du crédit et montant des prêts : une interprétation en terme de canal large du crédit », septembre 1995.

33. G. Cette et S. Mahfouz, «Le partage primaire du revenu: constat descriptif sur longue période », décembre 1995.

34. H. Pagès, "Is there a Premium for Currencies Correlated with Volatility? Some Evidence from Risk Reversals," January 1996.

35. E. Jondeau and R. Ricart, "The Expectations Theory: Tests on French, German and American Euro-rates," June 1996.

36. B. Bensaid et O. De Bandt, «Les stratégies "stop-loss" : théorie et application au Contrat Notionnel du Matif », juin 1996.

37. C. Martin et F. Rosenwald, «Le marché des certificats de dépôts. Écarts de taux à l'émission : l'influence de la relation émetteurs-souscripteurs initiaux », avril 1996. 
38. Banque de France - CEPREMAP - Direction de la Prévision - Erasme - INSEE - OFCE, « Structures et propriétés de cinq modèles macroéconomiques français », juin 1996.

39. F. Rosenwald, "L'influence des montants émis sur le taux des certificats de dépôts », octobre 1996.

40. L. Baumel, «Les crédits mis en place par les banques AFB de 1978 à 1992 : une évaluation des montants et des durées initiales », novembre 1996.

41. G. Cette et E. Kremp, «Le passage à une assiette valeur ajoutée pour les cotisations sociales : Une caractérisation des entreprises non financières "gagnantes" et "perdantes" ", novembre 1996.

42. S. Avouyi-Dovi, E. Jondeau et C. Lai Tong, «Effets "volume", volatilité et transmissions internationales sur les marchés boursiers dans le G5 », avril 1997.

43. E. Jondeau et R. Ricart, «Le contenu en information de la pente des taux : Application au cas des titres publics français », juin 1997.

44. B. Bensaid et M. Boutillier, « Le contrat notionnel : efficience et efficacité », juillet 1997.

45. E. Jondeau et R. Ricart, « La théorie des anticipations de la structure par terme : test à partir des titres publics français », septembre 1997.

46. E. Jondeau, «Représentation VAR et test de la théorie des anticipations de la structure par terme », septembre 1997.

47. E. Jondeau et M. Rockinger, «Estimation et interprétation des densités neutres au risque : Une comparaison de méthodes », octobre 1997.

48. L. Baumel et P. Sevestre, «La relation entre le taux de crédits et le coût des ressources bancaires. Modélisation et estimation sur données individuelles de banques », octobre 1997.

49. P. Sevestre, "On the Use of Banks Balance Sheet Data in Loan Market Studies : A Note," October 1997.

50. P.-C. Hautcoeur and P. Sicsic, "Threat of a Capital Levy, Expected Devaluation and Interest Rates in France during the Interwar Period," January 1998.

51. P. Jacquinot, «L'inflation sous-jacente à partir d'une approche structurelle des VAR : une application à la France, à l'Allemagne et au Royaume-Uni », janvier 1998.

52. C. Bruneau et $\mathrm{O}$. De Bandt, «La modélisation VAR structurel : application à la politique monétaire en France », janvier 1998.

53. C. Bruneau and E. Jondeau, "Long-Run Causality, with an Application to International Links between Long-Term Interest Rates," June 1998.

54. S. Coutant, E. Jondeau and M. Rockinger, "Reading Interest Rate and Bond Futures Options' Smiles: How PIBOR and Notional Operators Appreciated the 1997 French Snap Election," June 1998.

55. E. Jondeau et F. Sédillot, « La prévision des taux longs français et allemands à partir d'un modèle à anticipations rationnelles », juin 1998. 
56. E. Jondeau and M. Rockinger, "Estimating Gram-Charlier Expansions with Positivity Constraints," January 1999.

57. S. Avouyi-Dovi and E. Jondeau, "Interest Rate Transmission and Volatility Transmission along the Yield Curve," January 1999.

58. S. Avouyi-Dovi et E. Jondeau, «La modélisation de la volatilité des bourses asiatiques », janvier 1999.

59. E. Jondeau, «La mesure du ratio rendement-risque à partir du marché des euro-devises », janvier 1999.

60. C. Bruneau and O. De Bandt, "Fiscal Policy in the Transition to Monetary Union: A Structural VAR Model," January 1999.

61. E. Jondeau and R. Ricart, "The Information Content of the French and German Government Bond Yield Curves: Why Such Differences?," February 1999.

62. J.-B. Chatelain et P. Sevestre, «Coûts et bénéfices du passage d'une faible inflation à la stabilité des prix », février 1999.

63. D. Irac et P. Jacquinot, « L’investissement en France depuis le début des années 1980 », avril 1999.

64. F. Mihoubi, « Le partage de la valeur ajoutée en France et en Allemagne », mars 1999.

65. S. Avouyi-Dovi and E. Jondeau, "Modelling the French Swap Spread," April 1999.

66. E. Jondeau and M. Rockinger, "The Tail Behavior of Stock Returns: Emerging Versus Mature Markets," June 1999.

67. F. Sédillot, «La pente des taux contient-elle de l'information sur l'activité économique future? », juin 1999.

68. E. Jondeau, H. Le Bihan et F. Sédillot, «Modélisation et prévision des indices de prix sectoriels », septembre 1999.

69. H. Le Bihan and F. Sédillot, "Implementing and Interpreting Indicators of Core Inflation: The French Case," September 1999.

70. R. Lacroix, "Testing for Zeros in the Spectrum of an Univariate Stationary Process: Part I," December 1999.

71. R. Lacroix, "Testing for Zeros in the Spectrum of an Univariate Stationary Process: Part II," December 1999.

72. R. Lacroix, "Testing the Null Hypothesis of Stationarity in Fractionally Integrated Models," December 1999.

73. F. Chesnay and E. Jondeau, "Does correlation between stock returns really increase during turbulent period?," April 2000.

74. O. Burkart and V. Coudert, "Leading Indicators of Currency Crises in Emerging Economies," May 2000.

75. D. Irac, "Estimation of a Time Varying NAIRU for France," July 2000. 
76. E. Jondeau and H. Le Bihan, "Evaluating Monetary Policy Rules in Estimated ForwardLooking Models: A Comparison of US and German Monetary Policies," October 2000.

77. E. Jondeau and M. Rockinger, "Conditional Volatility, Skewness, ans Kurtosis: Existence and Persistence," November 2000.

78. P. Jacquinot et F. Mihoubi, «Modèle à Anticipations Rationnelles de la COnjoncture Simulée : MARCOS », novembre 2000.

79. M. Rockinger and E. Jondeau, "Entropy Densities: With an Application to Autoregressive Conditional Skewness and Kurtosis," January 2001.

80. B. Amable and J.-B. Chatelain, "Can Financial Infrastructures Foster Economic Development? ,"January 2001.

81. J.-B. Chatelain and J.-C. Teurlai, "Pitfalls in Investment Euler Equations," January 2001.

82. M. Rockinger and E. Jondeau, "Conditional Dependency of Financial Series: An Application of Copulas," February 2001.

83. C. Florens, E. Jondeau and H. Le Bihan, "Assessing GMM Estimates of the Federal Reserve Reaction Function," March 2001.

84. J.-B. Chatelain, "Mark-up and Capital Structure of the Firm facing Uncertainty," June 2001.

85. B. Amable, J.-B. Chatelain and O. De Bandt, "Optimal Capacity in the Banking Sector and Economic Growth," June 2001.

86. E. Jondeau and H. Le Bihan, "Testing for a Forward-Looking Phillips Curve. Additional Evidence from European and US Data," December 2001.

87. G. Cette, J. Mairesse et Y. Kocoglu, «Croissance économique et diffusion des TIC : le cas de la France sur longue période (1980-2000) », décembre 2001.

88. D. Irac and F. Sédillot, "Short Run Assessment of French Economic Activity Using OPTIM,” January 2002.

89. M. Baghli, C. Bouthevillain, O. de Bandt, H. Fraisse, H. Le Bihan et Ph. Rousseaux, «PIB potentiel et écart de PIB : quelques évaluations pour la France », juillet 2002.

90. E. Jondeau and M. Rockinger, "Asset Allocation in Transition Economies," October 2002.

91. H. Pagès and J.A.C. Santos, "Optimal Supervisory Policies and Depositor-Preferences Laws," October 2002.

92. C. Loupias, F. Savignac and P. Sevestre, "Is There a Bank Lending Channel in France? Evidence from Bank Panel Data," November 2002.

93. M. Ehrmann, L. Gambacorta, J. Martínez-Pagés, P. Sevestre and A. Worms, "Financial Systems and The Role in Monetary Policy Transmission in the Euro Area," November 2002.

94. S. Avouyi-Dovi, D. Guégan et S. Ladoucette, «Une mesure de la persistance dans les indices boursiers », décembre 2002. 
95. S. Avouyi-Dovi, D. Guégan et S. Ladoucette, "What is the Best Approach to Measure the Interdependence between Different Markets? ," December 2002.

96. J.-B. Chatelain and A. Tiomo, "Investment, the Cost of Capital and Monetary Policy in the Nineties in France: A Panel Data Investigation," December 2002.

97. J.-B. Chatelain, A. Generale, I. Hernando, U. von Kalckreuth and P. Vermeulen, "Firm Investment and Monetary Policy Transmission in the Euro Area," December 2002.

98. J.-S. Mésonnier, «Banque centrale, taux de l'escompte et politique monétaire chez Henry Thornton (1760-1815) », décembre 2002.

99. M. Baghli, G. Cette et A. Sylvain, «Les déterminants du taux de marge en France et quelques autres grands pays industrialisés : Analyse empirique sur la période 1970-2000», janvier 2003.

100. G. Cette and Ch. Pfister, "The Challenges of the "New Economy" for Monetary Policy," January 2003.

101. C. Bruneau, O. De Bandt, A. Flageollet and E. Michaux, "Forecasting Inflation using Economic Indicators: the Case of France," May 2003.

102. C. Bruneau, O. De Bandt and A. Flageollet, "Forecasting Inflation in the Euro Area," May 2003.

103. E. Jondeau and H. Le Bihan, "ML vs GMM Estimates of Hybrid Macroeconomic Models (With an Application to the "New Phillips Curve")," September 2003.

104. J. Matheron and T.-P. Maury, "Evaluating the Fit of Sticky Price Models," January 2004.

105. S. Moyen and J.-G. Sahuc, "Incorporating Labour Market Frictions into an OptimisingBased Monetary Policy Model," January 2004.

106. M. Baghli, V. Brunhes-Lesage, O. De Bandt, H. Fraisse et J.-P. Villetelle, «MASCOTTE :

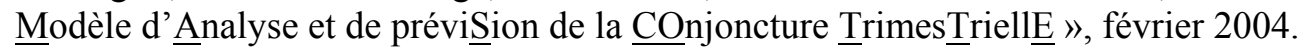

107. E. Jondeau and M. Rockinger, "The Bank Bias: Segmentation of French Fund Families," February 2004.

108. E. Jondeau and M. Rockinger, "Optimal Portfolio Allocation Under Higher Moments," February 2004.

109. C. Bordes et L. Clerc, «Stabilité des prix et stratégie de politique monétaire unique », mars 2004.

110. N. Belorgey, R. Lecat et T.-P. Maury, «Déterminants de la productivité par employé : une évaluation empirique en données de panel », avril 2004.

111. T.-P. Maury and B. Pluyaud, "The Breaks in per Capita Productivity Trends in a Number of Industrial Countries," April 2004.

112. G. Cette, J. Mairesse and Y. Kocoglu, "ICT Diffusion and Potential Output Growth," April 2004.

113. L. Baudry, H. Le Bihan, P. Sevestre and S. Tarrieu, "Price Rigidity. Evidence from the French CPI Micro-Data," September 2004. 
114. C. Bruneau, O. De Bandt and A. Flageollet, "Inflation and the Markup in the Euro Area," September 2004.

115. J.-S. Mésonnier and J.-P. Renne, "A Time-Varying "Natural" Rate of Interest for the Euro Area," September 2004.

116. G. Cette, J. Lopez and P.-S. Noual, "Investment in Information and Communication Technologies: an Empirical Analysis," October 2004.

117. J.-S. Mésonnier et J.-P. Renne, « Règle de Taylor et politique monétaire dans la zone euro », octobre 2004.

118. J.-G. Sahuc, "Partial Indexation, Trend Inflation, and the Hybrid Phillips Curve," December 2004.

119. C. Loupias et B. Wigniolle, « Régime de retraite et chute de la natalité : évolution des mœurs ou arbitrage micro-économique? », décembre 2004.

120. C. Loupias and R. Ricart, "Price Setting in France: new Evidence from Survey Data," December 2004.

121. S. Avouyi-Dovi and J. Matheron, "Interactions between Business Cycles, Stock Markets Cycles and Interest Rates: the Stylised Facts," January 2005.

122. L. Bilke, "Break in the Mean and Persistence of Inflation: a Sectoral Analysis of French CPI," January 2005.

123. S. Avouyi-Dovi and J. Matheron, "Technology Shocks and Monetary Policy in an Estimated Sticky Price Model of the US Economy," April 2005.

124. M. Dupaigne, P. Fève and J. Matheron, "Technology Shock and Employement: Do We Really Need DSGE Models with a Fall in Hours?," June 2005.

125. P. Fève and J. Matheron, "Can the Kydland-Prescott Model Pass the Cogley-Nason Test?," June 2005.

126. S. Avouyi-Dovi and J. Matheron, "Technology Shocks and Monetary Policy in an Estimated Sticky Price Model of the Euro Area," June 2005.

127. O. Loisel, "Central Bank Reputation in a Forward-Looking Model," June 2005.

128. B. Bellone, E. Gautier et S. Le Coent, «Les marchés financiers anticipent-ils les retournements conjoncturels? », juillet 2005.

129. P. Fève, « La modélisation macro-économétrique dynamique », juillet 2005.

130. G. Cette, N. Dromel and D. Méda, "Opportunity Costs of Having a Child, Financial Constraints and Fertility," August 2005.

131. S. Gouteron et D. Szpiro, « Excès de liquidité monétaire et prix des actifs », septembre 2005.

132. J. Baude, «L'impact des chocs boursiers sur le crédit en France depuis le milieu des années quatre-vingt-dix », septembre 2005.

133. R. Bourlès and G. Cette, "A Comparison of Structural Productivity Levels in the Major Industrialised Countries," October 2005. 
134. T. Grunspan, "The Fed and the Question of Financial Stability: An Empirical Investigation," October 2005.

135. S. Fabiani, M. Druant, I. Hernando, C. Kwapil, B. Landau, C. Loupias, F. Martins, T. Mathä, R. Sabbatini, H. Stahl and A. Stockman, "The Pricing Behaviour of Firms in the Euro Area: New Survey Evidence," November 2005.

136. E. Dhyne, L. Alvarez, H. Le Bihan, G. Veronese, D. Dias, J. Hoffmann, N. Jonker, P. Lünnemann, F. Rumler and J. Vilmunen, "Price Setting in the Euro Area: Some Stylized Facts from Individual Consumer Price Data," November 2005.

137. D. Fougère, H. Le Bihan and P. Sevestre, "Heterogeneity in Consumer Price Stickiness: A Microeconometric Investigation,” November 2005.

138. L. Alvarez, E. Dhyne, M. Hoeberichts, C. Kwapil, H. Le Bihan, P. Lünnemann, F. Martins, R. Sabbatini, H. Stahl, P. Vermeulen and J. Vilmunen, "Sticky Prices in the Euro Area: a Summary of New Micro Evidence," November 2005.

139. E. Kharroubi, "Illiquidity, Financial Development and the Growth-Volatility Relationship," February 2006.

140. M. Baghli, C. Cahn and H. Fraisse, "Is the Inflation-Output Nexus Asymmetric in the Euro Area," April 2006.

141. E. Jondeau and J-G. Sahuc, "Optimal Monetary Policy in an Estimated DSGE Model of the Euro Area with Cross-country Heterogeneity," April 2006.

142. S. Avouyi-Dovi, M. Brun, A. Dreyfus, F. Drumetz, V. Oung et J.-G. Sahuc, « La fonction de demande de monnaie pour la zone euro : un réexamen », mai 2006.

143. C. Jardet, “Term Structure Anomalies : Term Premium or Peso Problem?” May 2006.

144. S. Avouyi-Dovi, R. Kierzenkowski and C. Lubochinsky, "Are Business and Credit Cycles Converging or Diverging? A comparison of Poland, Hungary, the Czech Republic and the Euro Area", May 2006.

145. O. De Bandt, C. Bruneau and A. Flageollet, "Assessing Aggregate Comovements in France, Germany and Italy. Using a Non Stationary Factor Model of the Euro Area” June 2006.

146. M. Baghli, C. Cahn and J-P. Villetelle, "Estimating Potential Output with a Production Function for France, Germany and Italy", June 2006.

147. E. Fonteny, «La désaisonnalisation des séries d'agrégats monétaires et de crédit à la Banque de France : aspects théoriques et mise en œuvre », juin 2006.

148. J. Matheron and C. Poilly, "How Well Does a Small Structural Model with Sticky Prices and Wages Fit Postwar U.S. Data", July 2006.

149. E. Kharroubi, "Financial (Dis)Integration,” July 2006.

150. J. Carrillo, P. Fève and J. Matheron, "Monetary Policy Inertia or Persistent Shocks?" July 2006.

151. C. Ewerhart, N. Cassola and N. Valla, "Declining Valuations and Equilibrium Bidding in Central Bank Refinancing Operations," August 2006. 
152. D. Fougère, « Réformes structurelles sur le marché du travail : quels enseignements peut-on tirer des études existantes », août 2006.

153. D. Irac, "Revisiting the proximity-concentration trade-off: Distance and Horizontal Foreign Direct Investment in OECD Countries," August 2006.

154. D. Irac and C. Minoiu, "Risk insurance in a Transition Economy: Evidence from Rural Romania," August 2006.

155. H. Lustig and A. Verdelhan, "The Cross-Section of Foreign Currency Risk Premia and Consumption Growth Risk," August 2006.

156. R. Bourlès and G. Cette, "Trends in "structural" productivity levels in the major industrialized countries," September 2006.

157. J.-S. Mésonnier, "The Reliability of Macroeconomic Forecasts based on Real Interest Rate Gap Estimates in Real Time: an Assessment for the Euro Area," October 2006.

158. O. de Bandt, C. Bruneau and W. El Amri, "Convergence in Household Credit Demand across Euro Area Countries: Evidence from Panel Data," October 2006.

159. J. Idier, "Stock Exchanges Industry Consolidation and Shock Transmission," December 2006.

160. E. Gautier, "The Behaviour of Producer Prices: Some Evidence from the French PPI Micro Data," December 2006.

161. O. Loisel, "Bubble-free interest-rate rules," December 2006.

162. J. Boivin and M. P. Giannoni, "DSGE Models in a Data-Rich Environment,” January 2007.

163. J. Coffinet, J. Matheron et C. Poilly, « Une évaluation structurelle du ratio de sacrifice dans la zone euro », janvier 2007.

164. P. Vermeulen, D. Dias, M. Dossche, E. Gautier, I. Hernando, R. Sabbatini and H. Stahl, "Price setting in the euro area: Some stylised facts from Individual Producer Price Data," February 2007.

165. C. Bordes, L. Clerc and V. Marimoutou, "Is there a structural break in equilibrium velocity in the euro area?" February 2007.

Pour tous commentaires ou demandes sur les Notes d'Études et de Recherche, contacter la bibliothèque de la direction de la recherche à l'adresse suivante :

For any comment or enquiries on the Working Papers, contact the library of the Research Directorate at the following address :

\author{
BANQUE DE FRANCE \\ 41- 1404 Labolog \\ 75049 Paris Cedex 01 \\ tél : $0033(0) 142924955$ ou 6265 \\ fax :0033 (0)1 42926292 \\ email : thierry.demoulin@banque-france.fr \\ jeannine.agoutin@banque-france.fr
}

